\title{
Analisis Deskriptif Risiko BBLR (Bayi Berat Lahir Rendah) Di RSUP Dr. Tadjuddin Chalid Makassar
}

\author{
Ribka Rerung Layuk \\ RSUP dr. Tadjuddin Chalid Makassar \\ ribkarerunglayuk@gmail.com
}

\begin{abstract}
L B W$ is an indicator of public health degree in each country, because through the $L B W$ rate it is reflected in health services for maternal and children. The incidence of $L B W$ in infants does not only have an impact on neonates, but also has an impact on the growth and subsequent development of children because LBW occurs as a consequence of the disruption of growth and development of the fetus in the womb. This study aims to provide an overview of the incidence of LBW in 2018-2020 at the dr. Tadjuddin Chalid Hospital Makassar. Research method was descriptif. The variables in this study were LBW, sex, choice of treatment class, and complications of LBW. Data were taken using a total sampling technique sourced from Registration of Inpatients RSUP dr. Tadjuddin Chalid Makassa. The cleaned data is then analysis by descriptively. The results showed that LBW cases experienced a significant decrease from 2018-2020; Based on sex, boy and girl have the same probability of experiencing $L B W$, while based on the selected treatment class, most LBW babies are treated in a class Third treatment room. The most common occurrence is neonatal sepsis, so the risk of death can occur in neonates for infants with $L B W$.
\end{abstract}

Keywords: LBW, sex, complication, sosioeconomic status

\begin{abstract}
Abstrak: BBLR merupakan indikator derajad kesehatan masyarakat di suatu negara, karena melalui angka BBLR tercerminan pelayanan kesehatan bagi ibu dan anak. Kejadian BBLR pada bayi tidak hanya memberikan dampak pada neonatus, namun memberikan dampak bagi pertumbuhan dan perkembangan anak selanjutnya oleh karena BBLR terjadi sebagai konsekuensi dari terganggunya pertumbuhan dan perkembangan calon bayi sejak dalam dalam kandungan. Penelitian ini bertujuan untuk memberikan gambaran kejadian BBLR Tahun 2018-2020 di RSUP dr. Tadjuddin Chalid Makassar. Metode penelitian menggunakan penelitian deskriptif Variabel dalam penelitian ini adalah BBLR, jenis kelamin, pilihan kelas perawatan, dan komplikasi BBLR pada bayi. Data diambil menggunakan teknik total sampling yang bersumber dari Register Pasien Rawat Inap di RSUP dr. Tadjuddin Chalid Makassar. Data yang telah dicleaning kemudian diolah secara deskriptif. Hasil penelitian menunjukkan bahwa kasus BBLR mengalami penurunan yang signifikan dari Tahun 2018-2020; Berdasarkan jenis kelamin, laki-laki dan perempuan memiliki probabilitas yang sama untuk mengalami BBLR, sedangkan berdasarkan kelas perawatan yang dipilih, sebagian besar bayi BBLR dirawat pada ruang perawatan kelas 3.Berdasarkan komplikasi yang terjadi, sebagian besar bayi BBLR mengalami komplikasi, dan komplikasi yang paling banyak terjadi adalah sepsis neonatus, sehingga risiko kematian dapat terjadi pada masa neonatus bagi bayi dengan BBLR.
\end{abstract}

Kata kunci: BBLR, jenis kelamin, komplikasi, status sosial ekonomi 


\section{Pendahuluan}

Setiap negara memiliki tanggung jawab untuk menjamin warga negara memperoleh hak dasarnya, misalnya kesehatan. Negara wajib untuk memberikan jaminan kesehatan ${ }^{1}$ sejak sebelum lahir hingga akhir hayat seseorang. Adanya penurunan angka kematian ibu dan anak merupakan salah satu indikator keberhasilan suatu negara dalam upaya pencapaian derajat kesehatan masyarakat yang optimal. Hingga kini, dunia masih mengahadapi berbagai masalah kesehatan ibu dan anak yang menjadi faktor penting yang menentukan baik buruknya kesehatan suatu bangsa yaitu tingginya AKB (Angka Kematian Bayi). Oleh karena itu, seluruh dunia berupaya untuk menurunkan AKB. MDGs (Millenium Development Goals) merupakan salah satu organisasi dunia yang turut memperhatikan masalah AKB dengan merumuskan tujuan ke empatnya yaitu menurunkan angka kematian anak, termasuk balita. Pada tahun 2018, sebanyak 4 juta atau 75\% dari semua kematian balita umumnya terjadi pada awal kehidupan. Kasus tertinggi risiko kematian anak di awal kehidupan terjadi di Wilayah Afrika yaitu 52 kematian per 1000 kelahiran hidup. Kasus ini tujuh kali lebih tinggi daripada di Wilayah Eropa yaitu sebanyak 7 kematian per 1000 kelahiran hidup. Namun secara global, AKB cenderung mengalami penurunan dari tahun ke tahun. Pada tahun 2017 sebanyak 30 per 1000 kelahiran hidup, tahun 2018 sebanyak 29 per 1000 kelahiran hidup, dan tahun 2019 sebanyak 28 per 1000 kelahiran hidup. ${ }^{2}$

Data statistik WHO (World Health Organization), AKB di Indonesia menunjukkan adanya penurunan kejadian selama 4 tahun terakhir. Pada tahun 2018, AKB di Indonesia sebanyak 18.909 per 1000 kelahiran hidup, turun 6,08\% dari tahun 2017. Tahun 2019, turun sebesar 3,16\% dari tahun 2018 yaitu sebanyak 18.311 per 1000 kelahiran hidup dan pada tahun 2020 sebesar 3,27\% dari tahun 2019 yaitu sebanyak 17.713 per 1000 kelahiran hidup. Hingga tahun 2021, terjadi penurunan AKB di Indonesia sebesar 3,37\% dari tahun 2020 yaitu 17,116 per 1000 kelahiran hidup ${ }^{3}$

Ada banyak faktor yang menyebabkan tingginya AKB, khususnya pada bayi neonatal. Namun, faktor risiko yang paling berkontribusi terhadap kematian bayi neonatal adalah BBLR (Berat Badan Lahir Rendah). Pada tahun 2019, penyebab kematian neonatal (0-28 hari) terbanyak adalah kondisi BBLR pada bayi yaitu sebesar 35.3\% ${ }^{4}$

\footnotetext{
${ }^{1}$ Republik Indonesia, Kesehatan (Republik Indonesia: Kementerian Kesehatan, 2009), Infeksiemerging.kemkes.go.id.

2World Health Organization, "Newborns with Low Birth Weight."

${ }^{3}$ World Health Organization, Infant Mortality (Genewa, 2021).

${ }^{4}$ Adi Sresti Sagung Mahayana and et al, "Faktor Risiko Yang Berpengaruh Terhadap Kejadian Berat Badan Lahir Rendah Di RSUP Dr. M. Djamil Padang," Jurnal Kesehatan Andalas 4, no. 3 (2015).
} 
BBLR adalah bayi yang lahir dengan kondisi berat badan lahir kurang dari 2.500 gram (5.5 pon). Bayi dengan BBLR memiliki peluang hidup sangat kecil dan risiko untuk mengalami kematian lebih tinggi yaitu sebanyak 20 kali jika dibandingkan dengan bayi yang lahir dengan berat badan normal. Selain itu, BBLR jika bertahan hidup, akan mengalami berbagai masalah kesehatan, seperti : masalah pertumbuhan dan perkembangan kognitif dan penyakit degeneratif pada saat dewasa ${ }^{5}$.

Prevalensi BBLR secara global pada tahun 2015 yaitu sebesar 14,6\%. BBLR secara statistik lebih banyak terjadi di negara berkembang daripada negara maju. Sebanyak $3 / 4$ dari keseluruhan kasus BBLR di dunia terjadi di tiga wilayah yaitu : Asia Selatan sebesar 47\%, Afrika Timur dan Selatan sebesar 13\%, dan Afrika Barat dan Tengah sebesar 12\%. Meskipun tampaknya ada beberapa peningkatan jumlah BBLR tahun 2000 hingga 2015 di wilayah Afrika Barat dan Tengah serta Afrika Timur dan Selatan, satu-satunya wilayah yang mengalami peningkatan yang signifikan secara statistik adalah Amerika Utara yaitu 315.684 kasus pada tahun 2000 dan 345.743 kasus pada tahun $2015 .^{6}$

Di Indonesia, proporsi BBLR pada anak umur 0-59 bulan yaitu sebesar 6,2\% (RISKESDAS, 2018). Jumlah kejadian BBLR di Provinsi Sulawesi Selatan pada tahun 2015 yaitu sebanyak 5.956 kasus dari 148.929 kelahiran bayi. Sedangkan di Kota Makassar, kasus BBLR pada tahun yang sama yaitu sebanyak 1.415 kasus dari 25.182 kelahiran bayi. $^{7}$

Berdasarkan data yang bersumber dari Register Pasien Rawat Inap di Rumah Sakit Umum Pusat dr. Tadjuddin Chalid Makassar tahun 2018 sampai dengan tahun 2020, kasus bayi yang lahir dengan BBLR sebanyak 124 orang dengan 12 kematian (9.7\%) selama bayi tersebut dirawat inap di rumah sakit. Jika data dilihat per tahun, angka kematian BBLR (Bayi Berat Lahir Rendah) cenderung meningkat yaitu tahun 2018 sebesar 3.9\%, tahun 2019 sebesar $11.4 \%$, dan tahun 2020 sebesar $41.6 \%$.

Menurut WHO, BBLR dapat disebabkan oleh hambatan pertumbuhan intrauterin, prematur, atau keduanya. Namun, menurut berbagai penelitian yang telah dilakukan, BBLR dapat terjadi akibat faktor ibu (maternal), seperti :, usia ibu ( $<20$ tahun dan $>35$ tahun), jarak kehamilan terlalu dekat, gizi saat hamil kurang, tingkat pendidikan, status sosial ekonomi, dan pekerjaan. Selain itu, faktor bayi dan janin juga dapat mempengaruhi terjadinya BBLR (Bayi Berat Lahir Rendah) misalnya jenis kelamin bayi, cacat bawaan, dan infeksi dalam lahir. ${ }^{8}$

\footnotetext{
5UNICEF, “Low Birth Weight."

${ }^{6}$ Ibid.

${ }^{7}$ Badan Pusat Statistik Sulawesi Selatan, Jumlah Bayi Lahir, Bayi Berat Badan Lahir Rendah (BBLR), BBLR Dirujuk, Dan Bergizi Buruk Menurut Kabupaten/Kota Di Provinsi Sulawesi Selatan, 2015 (MAKASSAR, 2015). ${ }^{8}$ Wibowo Aprilya Putri, "Faktor Ibu Terhadap Kejadian Bayi Berat Lahir Rendah," Higea Journal of Public Health 1, no. 1 (2018).
} 
Lahirnya bayi dengan BBLR juga dipengaruhi oleh karakteristik jenis kelamin. Proporsi BBLR pada umur 0-59 bulan pada perempuan yaitu sebesar 6,7\% dan laki-laki sebesar 5,7\%.9 Namun, menurut berbagai penelitian, berdasarkan jenis kelamin, BBLR lebih banyak dialami oleh laki-laki dibandingkan dengan perempuan. Penelitian oleh Amima Fajriana, dkk (2018) menunjukkan bahwa kasus BBLR pada laki-laki sebesar 54,5\%.10 Demikianpun dengan penelitian Sagung Adi Sresti Mahayana, dkk (2015) dengan persentase sebesar $61,1 \%{ }^{11}$

Beberapa hal yang dapat mempengaruhi kejadian BBLR selain jenis kelamin, adalah adalah kondisi sosial ekonomi. Hal ini berkaitan dengan penghasilan keluarga. Pada umumnya, ibu dengan kondisi ekonomi lemah akan cenderung tidak memperhatikan pemenuhan gizi saat hamil sehingga mempengaruhi terjadinya BBLR. Penelitian oleh Supriyatun menunjukkan adanya hubungan status sosial ekonomi dengan kejadian BBLR di wilayah kerja Puskesmas Langensari I Kota Banjar dengan p-value $0,000<0,05 .^{12}$

Bayi yang lahir dengan kondisi BBLR dapat mengalami masalah kesehatan seperti imanturitas imunologis, kesulitan bernafas, kelainan gastrointestinal dan nutrisi, imaturitas hati dan ginjal, kelainan neurologis, kardiovaskuler, maupun hematologis, serta gangguan metabolisme. Hal ini dapat terjadi karena dipicu oleh ibu hamil yang malnutrisi atau kekurangan asupan nutrisi akan mengalami kondisi dimana volume darah berkurang, ukuran plasenta berkurang yang mengakibatkan asupan nutrisi bagi janin kurang sehingga janin mengalami tumbuh lambat atau terganggu. Kejadian BBLR pada bayi memiliki dampak tidak hanya pada saat bayi lahir berupa risiko kematian maupun komplikasi namun juga untuk perkembangan selanjutnya, seperti masalah pertumbuhan maupun perkembangan baik psikis maupun kognitif.

Berdasarkan gambaran tersebut, maka peneliti memandang perlu melakukan penelitian tentang BBLR. Tujuan dilakukannya penelitian tersebut adalah untuk mengetahui gambaran deskriptif risiko BBLR di RSUP dr. Tadjuddin Chalid Makassar Tahun 2021.

${ }^{9}$ KEMENTERIAN KESEHATAN REPUBLIK INDONESIA, Hasil Utama RISKESDAS Tahun 2018 (JAKARTA, 2018).

${ }^{10} \mathrm{Amima}$ Fajriana and Buanasita Annas, "FAKTOR RISIKO YANG BERHUBUNGAN DENGAN KEJADIAN BAYI BERAT LAHIR RENDAH DI KECAMATAN SEMAMPIR SURABAYA," Media Gizi Indonesia 13, no. 1 (2018).

${ }^{11}$ Mahayana and et al, "Faktor Risiko Yang Berpengaruh Terhadap Kejadian Berat Badan Lahir Rendah Di RSUP Dr. M. Djamil Padang."

${ }^{12}$ Supriyatun, “Hubungan Sosial Ekonomi Dengan Kejadian BBLR,” Jurnal Kesehatan 8, no. 2 (2017): 1. 


\section{Metode Penelitian}

Metode penelitian yang digunakan adalah penelitian kuantitatif, dengan desain penelitian deskriptif. Populasi dan sampel penelitian adalah bayi BBLR yang terjadi di RSUP dr. Tadjuddin Chalid Makassar Tahun 2018-2020. Pengambilan sampel dilakukan secara nonrandom dengan menggunakan metode total sampling, yaitu semua kasus BBLR yang terjadi di lokasi penelitian selama rentang waktu tiga tahun yaitu Tahun 2018-2020. Pengumpulan data menggunakan data sekunder yaitu data Register Pasien Rawat Inap di RSUP dr. Tadjuddin Chalid Makassar. Variabel penelitian terdiri atas: bayi BBLR, jenis kelamin, sosial ekonomi keluarga, dan komplikasi BBLR. Bayi dengan BBLR yaitu bayi yang didiagnosa BBLR dengan kriteria berat badan $<2.400$ gram atau melalui file register dengan kode International Code Diagnosis Edisi 10 atau ICD-X yaitu P07.0 dan P07.1; variabel jenis kelamin yaitu identitas biologi pasien BBLR (Bayi Berat Lahir Rendah) yang diketahui berdasarkan data kelahiran pasien/ data rekam medis bayi baru lahir; variabel sosial ekonomi didasarkan pada kelas perawatan pasien yaitu kelas perawatan dimana pasien BBLR dirawat; dan variabel komplikasi BBLR adalah komplikasi yang dialami oleh bayi berdasarkan data diagnosa sekunder. Data yang dikumpulkan kemudian diolah dan dianalisis secara deskriptif kemudian disajikan dalam bentuk grafik dan narasi.

\section{Hasil dan Pembahasan}

\section{Hasil Penelitian}

Hasil Analisa data Register Pasien Rawat Inap RSUP dr. Tadjuddin Chalid Makassar Tahun 2018 - 2020 yang memenuhi kriteria sampel menunjukkan hasil sebagai berikut:

\section{Berat Badan Lahir Rendah}

Berdasarkan diagnosa utama pasien rawat inap pada Register Pasien Rawat Inap RSUP dr. Tadjuddin Chalid Makassar, kasus BBLR terdiri atas dua kategori yaitu BBLASR (Berat Badan Lahir Amat Sangat Rendah) dan BBLR (Berat Badan Lahir Rendah). Distribusi pasien BBLR berdasarkan kategori tersebut, dapat dilihat pada Grafik 1.

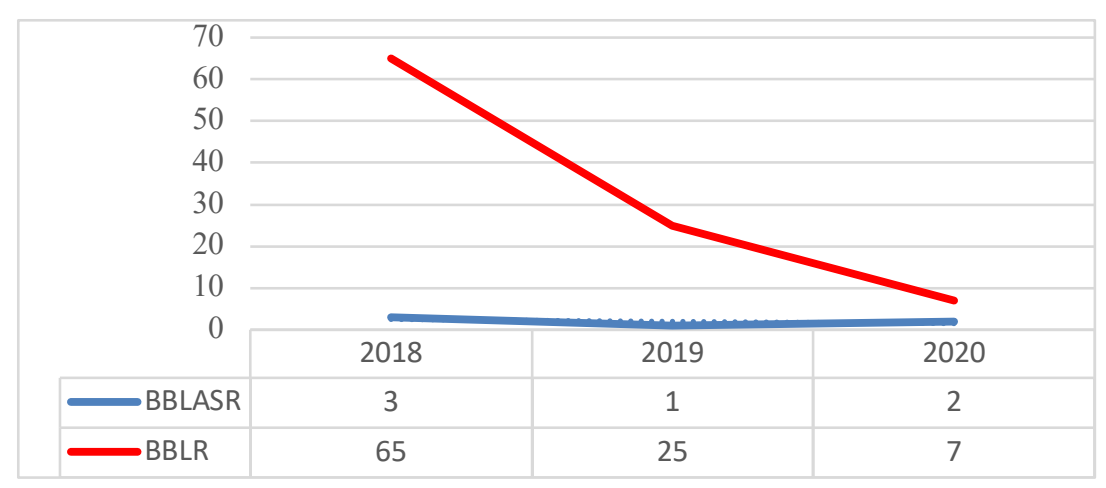

Grafik 1 Distribusi Frekuensi Kasus BBLR di RSUP dr. Tadjuddin Chalid Makassar Tahun 2018-2021 Sumber : Register Pasien Rawat Inap RSUP dr. Tadjuddin Chalid Makassar, 2018-2020 
Berdasarkan Grafik 1, dapat diketahui bahwa dari 103 bayi yang dirawat inap di RSUP dr. Tadjuddin Chalid Makassar, kasus BBLR lebih banyak terjadi daripada kasus BBLASR selama kurun waktu tiga tahun terakhir yaitu masing-masing sebanyak 97 kasus (94\%) dan 6 kasus (5\%). Dari grafik tersebut juga dapat diketahui bahwa kasus BBLR (Bayi Berat Lahir Rendah) di RSUP dr. Tadjuddin Chalid Makassar dari tahun 2018 sampai dengan tahun 2020 cenderung mengalami penurunan. Pada tahun 2018, kasus BBLR (Bayi Berat Lahir Rendah) sebanyak 65 kasus, kemudian tahun 2019 turun menjadi 25 kasus, dan pada tahun 2020 menjadi 7 kasus.

BBLR, baik secara global, regional, dan nasional terus menunjukkan angka penurunan. Penurunan ini terjadi menunjukkan keberhasilan upaya pemerintah dan berbagai organisasi untuk terus melakukan promosi kesehatan tentang kesehatan ibu dan anak. Upaya prmototif dan preventif yang dilakukan berupa peningkatan pengetahuan tentang kehamilan, perencanaan persalinan, dan pencegahan komplikasi melalui pelayanan antenatal care untuk memantau kesehatan ibu selama kehamilan dan buku KIA, suami siaga, cakupan penolong persalinan yang tidak lagi terpusat di kota namun melalui ketersediaan penolong persalinan di Polindes (Pondok Bersalin Desa) maupun PONED (Pelayanan Obstetri Neonatal Emergensi Dasar). ${ }^{13}$

\section{Jenis Kelamin}

Berdasarkan jenis kelamin pasien rawat inap pada Register Pasien Rawat Inap RSUP dr. Tadjuddin Chalid Makassar, kasus BBLR berdasarkan jenis kelamin bayi dapat dilihat pada Grafik 2.

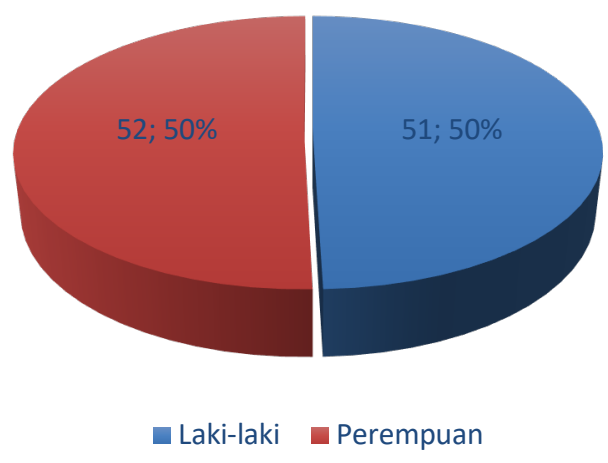

Grafik 2 Distribusi Frekuensi Kejadian BBLR Menurut Jenis Kelamin di RSUP dr. Tadjuddin Chalid Makassar Tahun 2018-2021

Sumber: Register Pasien Rawat Inap RSUP dr. Tadjuddin Chalid Makassar, 2018-2020

\footnotetext{
${ }^{13}$ Departemen Kesehatan, “Ibu Selamat, Bayi Sehat, Suami Siaga," Kemkes.Go.Id, last modified 2010, accessed June 12, 2020, kemkes.go.id.
} 
Grafik 2 menunjukkan bahwa berdasarkan karakteristik jenis kelamin, dari 103 BBLR di RSUP dr. Tadjuddin Chalid, kasus terbanyak terjadi pada perempuan yaitu sebanyak 52 bayi $(52,50 \%)$ sedangkan pada bayi laki-laki sebanyak 51 bayi $(51,50 \%)$. Dari gambaran deskriptif tersebut, dapat diketahui bahwa probabilitas kejadian BBLR berdasarkan jenis kelamin adalah sama.

\section{Status Sosial Ekonomi}

Berdasarkan kelas perawatan, dari 103 BBLR (Bayi Berat Lahir Rendah) di RSUP dr. Tadjuddin Chalid Makassar, sebanyak 7 bayi $(7,7 \%)$ mengambil kelas perawatan Kelas 1, sebanyak 11 bayi $(11,11 \%)$ Kelas 2, dan Kelas 3 sebanyak 85 bayi $(85,82 \%)$ mengambil kelas perawatan Kelas 3 (grafik 3). Data tersebut menunjukkan bahwa BBLR paling banyak terjadi pada keluarga dengan perawatan kelas 3.

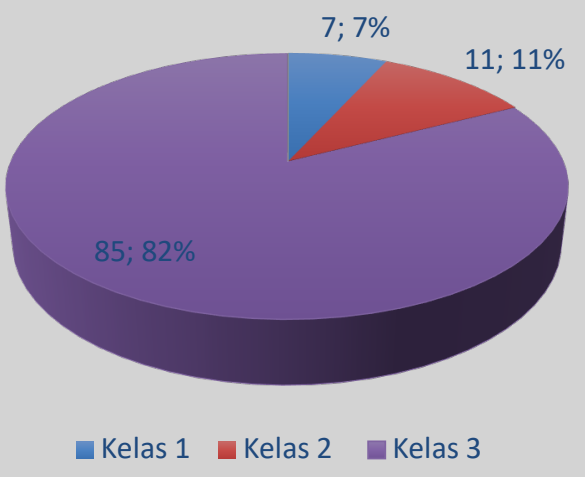

\section{Grafik 3 Distribusi Frekuensi Kejadian BBLR Menurut Kelas Perawatandi RSUP dr. Tadjuddin Chalid Makassar Tahun 2018-2021}

Sumber: Register Pasien Rawat Inap RSUP dr. Tadjuddin Chalid Makassar, 2018-2020

Pemilihan kelas perawatan khususnya bagi masyarakat Indonesia berhubungan dengan tingkat sosial ekonomi keluarga. ${ }^{14}$ Umumnya masyarakat dengan kondisi ekonomi yang lemah atau miskin adalah pengguna jaminan KIS (Kartu Indonesia Sehat) PBI (Penerima Bantuan Iuran) dari pemerintah yang kelas perawatannya adalah Kelas 3. Peserta BPJS Kesehatan PBI adalah peserta jaminan kesehatan bagi fakir miskin dan orang tidak mampu yang iurannya dibayarkan oleh pemerintah sebagaimana ditetapkan oleh pemerintah dan diatur melalui Peraturan Pemerintah. Hal ini didukung oleh penelitian oleh Supriyatun Supriyatun (2000) yang menunjukkan bahwa ada hubungan status sosial ekonomi dengan kejadian BBLR. Hasil penelitian menunjukkan bahwa kejadian BBLR banyak terjadi dialami oleh masyarakat miskin.

${ }^{14}$ Ida Untari, “Hubungan Antara Tingkat Sosial Ekonomi Keluarga Dengan Kepemilikan BPJS," Profesi. Media Publikasi Penelitian 12, no. 1 (2015): 1. 
Kemiskinan merupakan salah satu faktor yang menghambat masyarakat dalam memenuhi kebutuhan pangan. Kurangnya pendapatan atau penghasilan yang diperoleh menjadi alasan bagi ibu hamil dengan kondisi ekonomi lemah untuk memenuhi kebutuhan gizi yang seimbang, baik secara kuantitas maupun kualitas. Intake gizi oleh ibu hamil akan sangat mempengaruhi kesehatan ibu dan janin. Efek yang dapat ditimbulkan berupa pengaruh terhadap proses pertumbuhan dan perkembangan janin sehingga dapat menimbulkan kematian pada janin, kematian neonatal, dan gangguan kesehatan lainnya. Selain pemenuhan gizi. Umumnya masyarakat ekonomi lemah juga akan sulit untuk menjangkau pelayanan kesehatan dasar. Demikianpun halnya dengan ibu hamil. Ibu hamil dari keluarga miskin mengalami kesulitan dalam mengakses pelayanan dan informasi kesehatan.

Menurut penelitian yang Sagung Adi Sresti Mahayana, dkk (2015), status sosial ekonomi pada ibu sangat mempengaruhi kondisi bayi saat lahir. Pada umumnya, ibu hamil yang berasal dari keluarga dengan status ekonomi buruk memiliki rumah yang tidak memenuhi standar kesehatan dan beban pikiran yang lebih daripada ibu dari keluarga dengan status ekonomi baik. Hal ini dapat memicu terganggunya keseimbangan hormonal ibu.

\section{Komplikasi Bayi Berat Badan Lahir Rendah}

Kejadian BBLR terjadi karena kondisi bayi pada saat kehamilan, persalinan maupun adaptasi dengan kehidupan di luar rahim. Bayi dengan BBLR dapat menjadi indikator bahwa proses perkembangan dari janin menjadi bayi mengalami gangguan pertumbuhan maupun pematangan organ yang berdampak pada gangguan fungsi organ yang menyebabkan risiko gangguan perkembangan saraf yang buruk dan dapat menyebabkan kematian. Grafik 4 menunjukkan bahwa dari 103 bayi BBLR di RSUP dr. Tadjudidn Chalid Makassar selama Tahun 2018-2021 diketahui bahwa 3 komplikasi utama yang dialami bayi BBLR yaitu neonatal sepsis, peradangan usus dan gangguan pernafasan. Walaupun demikian terdapat 41 bayi atau $39 \%$ bayi tidak mengalami komplikasi. 


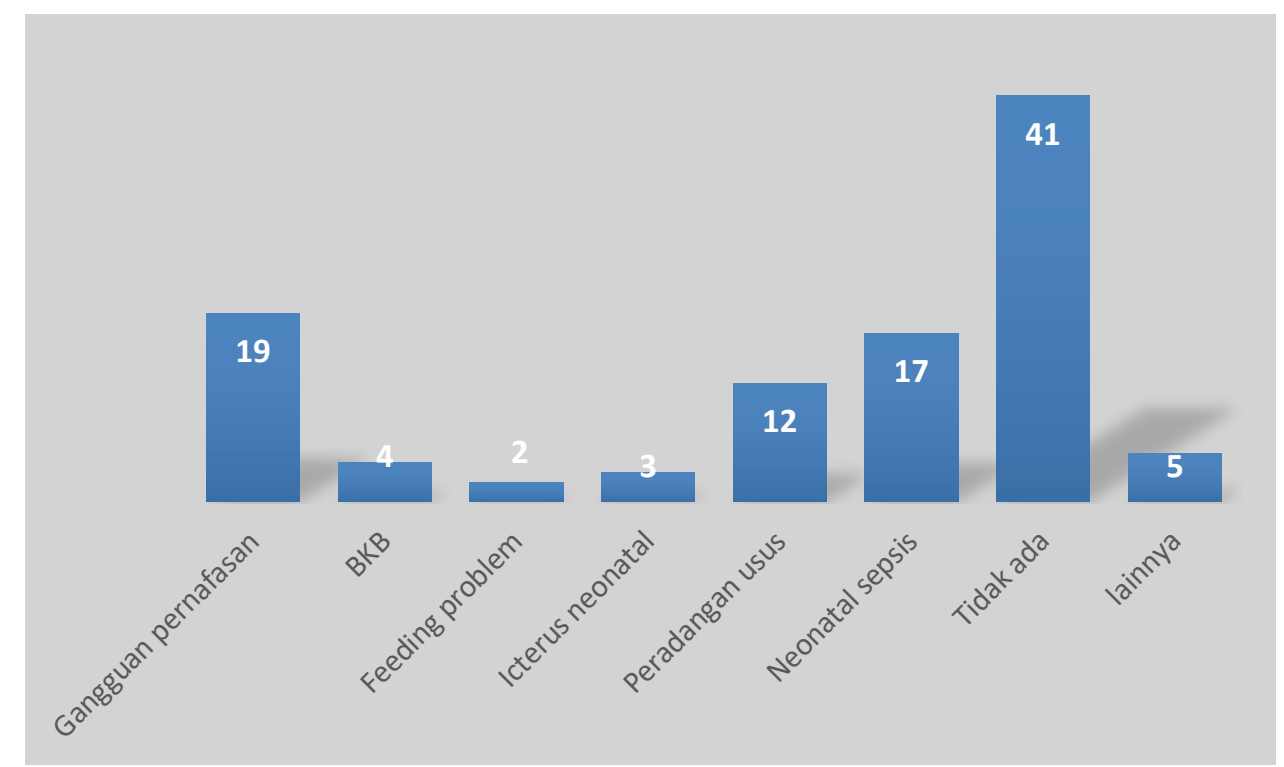

\section{Grafik 4 Distribusi Frekuensi Kejadian BBLR Menurut Komplikasi Bayi di RSUP dr. Tadjuddin Chalid Makassar Tahun 2018-2021}

Sumber: Register Pasien Rawat Inap RSUP dr. Tadjuddin Chalid Makassar, 2018-2020

Bayi yang belum cukup umur atau premature maupun bayi yang cukup umur namun memiliki hambatan dalam pertumbuhan selama proses kehamilan berisiko mengalami BBLR. ${ }^{15}$ Dampak komplikasi yang paling umum muncul akibat kejadian BBLR pada bayi adalah sepsis neonatus. Sepsis neonatus adalah suatu infeksi yang terjadi pada bayi yang baru lahir terutama bayi yang kurang bulan. Umumnya bayi premature memiliki imunitas yang rendah dibandingkan dengan bayi normal sehingga mudah terinfeksi oleh mikroorganisme. Sepsis neonatus merupakan penyakit infeksi yang sangat mempengaruhi keadaan morbiditas dan morbilitas bayi neonatus.

Infeksi ini disebabkan oleh berbagai mikrooganisme seperti bakteri gram negatif maupun positif, parasite, maupun jamur. ${ }^{16}$ Sekitar 30-50\% kasus kematian neonatal pada negara berkembang disebabkan oleh sepsis neonatus. Di India kasus neonatal sepsis sebesar 30 kematian per 1000 kelahiran hidup, dan berkontribusi 19\% dari total kematian neonatal. ${ }^{17}$ Pada bayi dengan BBLR, infeksi mungkin dapat terjadi pada masa kandungan akibat infeksi intrauterine yang disebabkan oleh kadar imunglobulin (IgG), sebagai perlindungan perlindungan tubuh, ${ }^{18}$ yang lebih rendah jika dibandingkan dengan bayi yang lahir normal. ${ }^{19}$ Kekurangan kadar IgG pada bayi BBLR menyebabkan bayi mudah mengalami infeksi, baik oleh bakteri, virus, dan mikroorganisme lainnya.

\footnotetext{
${ }^{15}$ World Health Organization, "Newborns with Low Birth Weight."

${ }^{16}$ Praevilia Margareth Salendu, "Sepsis Neonatorum Dan Pnemonia Pada Bayi Aterm," Jurnal Biomedik (JBM) 4, no. 3 (2012).

${ }^{17}$ Shashi Gandhy, K.Ranjan, and Masani Mehendra, "Incidence of Neonatal Spesis in Tertiary Care Hospital: AN Overview," International Journal of Medical Science and Public Health 2, no. 3 (2013). 
Kejadian sepsis pada bayi BBLR disebabkan oleh karena bayi dengan BBLR belum mengalami kematangan organ vital tubuh. Masalah lain yang terjadi pada bayi dengan BBLR adalah adanya penurunan berat badan yang tidak stabil dan terjadi kapan saja. Hal ini berbeda dengan bayi yang lahir normal, dimana pada awal kelahiran akan mengalami penurunan berat badan, namun kemudian berat badan akan meningkat sesuai dengan pertumbuhan bayi. Penurunan berat badan secara terus menerus ini terjadi karena terjadinya masalah dalam pemberian ASI maupun ketidakmampuan bayi dalam menghisap ASI karena adanya gangguan pada organ usus ataupun gangguan bawaan. Gangguan pernapasan pada bayi BBLR juga dapat diakibatkan oleh belum sempurnanya pusat pengaturan pernapasan serta otot pernapasan dan tulang iga yang masih lemah sehingga asupan oksigen ke otak berkurang. Tidak hanya berdampak pada gangguan pernapasan, namun kekurangan oksigen pada bayi juga dapat menyebabkan kuman anaerob mudah berkembang sehingga menimbulkan infeksi. ${ }^{20}$

Hasil penelitian ini menggambarkan bahwa BBLR merupakan masalah kesehatan ibu dan anak yang serius, oleh karena dampak dari kondisi yang dialami oleh bayi mencerminkan perkembangan dan pertumbuhan bayi. Adanya BBLR menunjukkan gangguan yang dialami oleh bayi. Ketidaksempurnaan pertumbuhan bayi, tentu menyebabkan ketidaksempurnaan dalam perkembangan organ-organ vital pada bayi tersebut. Dengan demikian risiko komplikasi yang dialami dapat terjadi, sebagai contoh dengan terganggunya aliran darah uteroplasenta menyebabkan bayi kekurangan imuniglobulin G yang berperan sebagai pembentuk kekebalan tubuh. Efeknya bayi akan lahir dengan imunitas yang rendah sehingga memungkinkan bayi untuk mudah terinfeksi oleh virus, bakteri maupun mikroorganisme lainnya. Selain itu gangguan perkembangan berdampak pada masalah usus menyebabkan bayi kesulitan untuk menyerap ASI yang diberikan, gangguan pernapasan memungkinkan bayi untuk mengalami sesak napas maupun kesulitan bernapas secara tiba-tiba.

\section{Kesimpulan}

Analisis deskripsi kasus BBLR yang terjadi di RSUP dr. Tadjuddin Chalid Makassar menunjukkan bahwa kejadian BBLR mengalami penurunan dari Tahun 2018-2020. Dari 103 kasus BBLR, bayi yang lahir dari keluarga dengan perawatan kelas 3 memiliki persentasi kasus BBLR yang tinggi, dan berdasarkan komplikasi yang terjadi, 59\% bayi dengan BBLR menunjukkan komplikasi dan berdampak pada risiko kematian pada neonatus. Dengan demikian, sangat penting memberikan edukasi kepada pasangan khususnya usia reproduksi dengan tingkat sosial ekonomi menengah ke bawah yang akan merencanakan program kehamilan untuk memahami pentingnya pemeriksaan kehamilan bagi ibu hamil melalui pelayanan antenatal care dengan demikian status gizi 
ibu dapat dimonitoring oleh tenaga kesehatan yang juga pada akhirnya memantau pemenuhan gizi janin untuk mencegah terjadinya risiko BBLR.

\section{Referensi}

Badan Pusat Statistik Sulawesi Selatan. Jumlah Bayi Lahir, Bayi Berat Badan Lahir Rendah (BBLR), BBLR Dirujuk, Dan Bergizi Buruk Menurut Kabupaten/Kota Di Provinsi Sulawesi Selatan, 2015. MAKASSAR, 2015.

Departemen Kesehatan. "Ibu Selamat, Bayi Sehat, Suami Siaga." Kemkes.Go.Id. Last modified 2010. Accessed June 12, 2020. kemkes.go.id.

Fajriana, Amima, and Buanasita Annas. "FAKTOR RISIKO YANG BERHUBUNGAN DENGAN KEJADIAN BAYI BERAT LAHIR RENDAH DI KECAMATAN SEMAMPIR SURABAYA." Media Gizi Indonesia 13, no. 1 (2018).

Gandhy, shashi, K.Ranjan, and Masani Mehendra. "Incidence of Neonatal Spesis in Tertiary Care Hospital: AN Overview." International Journal of Medical Science and Public Health 2, no. 3 (2013).

KEMENTERIAN KESEHATAN REPUBLIK INDONESIA. Hasil Utama RISKESDAS Tahun 2018. JAKARTA, 2018.

Mahayana, Adi Sresti Sagung, and et al. "Faktor Risiko Yang Berpengaruh Terhadap Kejadian Berat Badan Lahir Rendah Di RSUP Dr. M. Djamil Padang." Jurnal Kesehatan Andalas 4, no. 3 (2015).

Putri, Wibowo Aprilya. "Faktor Ibu Terhadap Kejadian Bayi Berat Lahir Rendah." Higea Journal of Public Health 1, no. 1 (2018).

Republik Indonesia. Kesehatan. Republik Indonesia: Kementerian Kesehatan, 2009. Infeksiemerging.kemkes.go.id.

Salendu, Praevilia Margareth. "Sepsis Neonatorum Dan Pnemonia Pada Bayi Aterm." Jurnal Biomedik (JBM) 4, no. 3 (2012).

Supriyatun. "Hubungan Sosial Ekonomi Dengan Kejadian BBLR.” Jurnal Kesehatan 8, no. 2 (2017): 1.

UNICEF. "Low Birth Weight."

Untari, Ida. "Hubungan Antara Tingkat Sosial Ekonomi Keluarga Dengan Kepemilikan BPJS." Profesi. Media Publikasi Penelitian 12, no. 1 (2015): 1.

World Health Organization. Infant Mortality. Genewa, 2021.

_-_. "Newborns with Low Birth Weight." 